Magdalena Proczek

\title{
DZIAŁALNOŚĆ MIĘDZYNARODOWEGO FUNDUSZU WALUTOWEGO NA RZECZ RÓWNOWAŻENIA ROZWOJU PAŃSTW CZŁONKOWSKICH
}

\section{Wprowadzenie}

Chociaż koncepcja zrównoważonego rozwoju nabrała międzynarodowego charakteru już ponad 40 lat temu podczas konferencji Organizacji Narodów Zjednoczonych w sprawie Środowiska Człowieka w Sztokholmie (w 1972 r.) $)^{1}$, to zwiększone zaangażowanie MFW w tę strategię widoczne jest dopiero od połowy lat 90. XX w. Głównymi obszarami działalności Funduszu związanymi z realizacją strategii zrównoważonego rozwoju są: pomoc kredytowa (zwłaszcza preferencyjna), redukcja zadłużenia, pomoc techniczna, nadzór nad polityką kursową i systemem finansowym państw członkowskich.

Środki finansowe przekazywane przez MFW państwom członkowskim mają formę zwrotnej pożyczki. Fundusz udziela pomocy członkom z zasobów własnych oraz pożyczonych. Kredyty udzielane są $\mathrm{w}$ formie sprzedaży państwom walut obcych za ich własne waluty, z obowiązkiem odwrotnej transakcji w określonym terminie ${ }^{2}$. Pożyczka jest udzielana na podstawie porozumienia z Funduszem, które w zależności od danego instrumentu finansowego może mieć charakter ogólny lub uprzywilejowany. Pomoc udostępniana przez MFW jest w zasadzie proporcjonalna do wpłaty danego państwa do kapitału zakładowego. Uzyskanie finansowania poprzedzają negocjacje członka z Funduszem dotyczące warunków programu dostosowawczego, kwoty pożyczki oraz wyboru instrumentu finansowego, który ma stanowić podstawę wsparcia. Wniosek danego państwa jest przedstawiany Radzie Administracyjnej Funduszu w postaci listu intencyjnego. Po zaaprobowaniu porozumienia przez Radę następuje przekazanie środków finansowych na zasadzie transz kredyto-

${ }^{1} \mathrm{~K}$. Bzdawka, Globalne dylematy a zrównoważony rozwój, w: Ochrona środowiska a procesy integracji i globalizacji, red. A. Budnikowski, M. Cygler, Oficyna Wydawnicza SGH, Warszawa 2004, s. 32.

${ }^{2}$ L. Dicks-Mireaux, M. Mecagni, S. Schadler, Evaluating the Effect of IMF Lending to Low-Income Countries, „Journal of Development Economies” 2000, Vol. 61, s. 504. 
wych. Wypłata każdej kolejnej transzy następuje przeważnie po ocenie przez MFW skuteczności realizacji programu dostosowawczego przez danego pożyczkobiorcę i jest wypłacana zazwyczaj w cyklu kwartalnym. Powyższa procedura daje Funduszowi możliwość wpływu na efektywność reform strukturalnych, których celem jest poprawienie sytuacji gospodarczej państwa występującego o finansowanie. Zgodnie z decyzją Rady Administracyjnej MFW z 24 marca 2009 r. górny limit pożyczek wynosi obecnie $200 \%$ wartości wkładu danego państwa do kapitału zakładowego rocznie i nie więcej niż 600\% łącznie. Niekiedy Fundusz może po indywidualnej ocenie sytuacji w państwie otrzymującym pożyczkę podwyższyć maksymalne limity ${ }^{3}$. Dla państw nieposiadających dobrej pozycji na rynkach finansowych i państw najuboższych pożyczki z MFW są często jedyną możliwością pozyskania finansowania zewnętrznego, często preferencyjnego.

Przyczyniając się do realizacji strategii zrównoważonego rozwoju, MFW podjął od 1996 r. współpracę z Międzynarodowym Bankiem Odbudowy i Rozwoju oraz innymi organizacjami międzynarodowymi w celu zmniejszenia skali zadłużenia państw najuboższych. Fundusz zapewnia także państwom członkowskim grupy LICs (Low-Income Countries) pomoc techniczną oraz sprawuje nadzór nad systemem finansowym, by zapewnić długookresową stabilność gospodarczą i społeczną, a także zrównoważony rozwój.

Celem opracowania jest analiza działalności MFW na rzecz realizacji strategii zrównoważonego rozwoju, a zwłaszcza zbadanie ewolucji jego pomocy preferencyjnej, przedstawienie inicjatyw Funduszu związanych z redukcją zadłużenia zewnętrznego państw oraz pomocy technicznej i nadzoru w celu tworzenia miejsc pracy, zmniejszenia nierówności gospodarczych i społecznych oraz zwiększenia ochrony socjalnej jako najważniejszych filarów ekonomicznych realizacji tej koncepcji przez MFW4.

\section{Ewolucja preferencyjnej pomocy finansowej MFW}

Podstawowy obszar wsparcia MFW dla najuboższych państw członkowskich preferencyjna pomoc kredytowa ulegała na przestrzeni lat ewolucji, by jak najlepiej sprostać potrzebom beneficjentów tej pomocy i efektywnie przyczyniać się do realizacji strategii zrównoważonego rozwoju przez eliminację ubóstwa oraz nierówności

${ }^{3}$ IMF Overhauls Nonconcessional Lending Facilities and Conditionality, http://www.imf.org/external/ $\mathrm{np} / \mathrm{sec} / \mathrm{pn} / 2009 / \mathrm{pn} 0940 . \mathrm{htm}$ [dostęp 4.09.2013].

${ }^{4}$ IMF Sets Path for Sustainable Development, http://www.imf.org/external/pubs/ft/survey/so/2012/ new062512a.htm [dostęp 4.09.2013]. 
gospodarczych i społecznych, a w efekcie osiągnięcie trwałego, wysokiego poziomu wzrostu gospodarczego ${ }^{5}$.

Pierwsza pożyczka na preferencyjnych warunkach skierowana do państw rozwijających się została udzielona przez MFW Peru w 1954 r. Pomoc ta trwała przez 4 lata i miała na celu przystosowanie wysokości kursu walutowego tego państwa do koniecznej wartości wynikającej z malejących rezerw dewizowych. Warunkiem udzielenia tej pomocy było zobligowanie się rządu Peru do zmniejszenia krajowej konsumpcji przez ustabilizowanie sytuacji fiskalnej. Wymagało to również od tego państwa zaniechania kontynuacji niektórych inwestycji oraz przełożenia w czasie kolejnych wydatków inwestycyjnych ${ }^{6}$.

W latach 70. XX w. dzięki powstaniu Funduszu Powierniczego (Trust Fund) ubogie państwa członkowskie, które zmagały się z nierównowagą bilansu płatniczego, mogły uzyskać pomoc kredytową od MFW na specjalnych warunkach. Preferencyjne pożyczki miały wydłużony okres spłaty oraz niskie oprocentowanie ${ }^{7}$. Środki zostały postawione do dyspozycji na $0,5-1 \%$ rocznie. Obniżenie oprocentowania było możliwe ze względu na istnienie specjalnych rachunków subwencyjnych, które tworzone były najczęściej z dodatkowych wpłat dokonywanych przez uprzemysłowione lub naftowe państwa członkowskie ${ }^{8}$. Do tego typu rachunków należały m.in. Oil Facility Subsidy Account oraz Supplementary Financing Facility Subsidy Account.

Pierwszych wypłat z Funduszu Powierniczego dokonano w 1977 r. Pomoc została udzielona 12 słabo rozwiniętym państwom. Środki finansowe na ten cel pozyskano dzięki sprzedaży części złota będącego w posiadaniu Funduszu. Następne sprzedaże kruszcu w latach 1976-1980 pozwoliły na udzielenie pomocy przez MFW kolejnym 12 państwom. Fundusz Powierniczy został zlikwidowany w roku $1981^{9}$. Ostateczna liczba państw, które skorzystały z pomocy, wyniosła 55. Pożyczki spłacano po 5,5 roku, a całość została zwrócona po 10 latach.

W latach 80. XX w. kryzys zadłużeniowy na świecie wywołał trudności w pozyskaniu finansowania zewnętrznego przez wiele państw, zwłaszcza w Ameryce Łacińskiej oraz Afryce. MFW ponownie interweniował, a jego rola nie ograniczała się jedynie do stawiania do dyspozycji środków finansowych. Fundusz podejmował liczne

${ }^{5}$ The IMF and the Millennium Development Goals, http://www.imf.org/external/np/exr/facts/mdg. htm [dostęp 4.09.2013].

6 J.R. Vreeland, The International Monetary Fund, Politics of Conditional Lending, Routledge Taylor \& Francis Group, London-New York 2007, s. 22.

7 T. Michałowski, Międzynarodowy Fundusz Walutowy. Działalność i propozycje reformy, Wydawnictwo UG, Gdańsk 2008, s. 194.

${ }^{8}$ Ibidem, s. 123-124.

${ }^{9}$ G. Bird, The International Monetary System and the Less Developed Countries, The Macmillan Press Ltd, London 1978, s. 207. 
próby odbudowania kontaktów między państwami zadłużonymi a ich wierzycielami. Oprócz tego zajął się koordynowaniem spłat pożyczek i kredytów udzielonych wcześniej poszczególnym państwom przez banki. Był to również okres, w którym MFW zaczął czynnie angażować się w proces tworzenia programów stabilizacyjnych $\mathrm{w}$ celu zbudowania trwałych podstaw zrównoważonego rozwoju ekonomicznego ${ }^{10}$.

Po raz kolejny pomoc preferencyjna została udzielona przez MFW w połowie lat 80 . XX w. Nowy rodzaj udogodnień został wprowadzony w 1986 r. Były to tzw. ułatwienia dostosowań strukturalnych (Structural Adjustment Facility - SAF), które rok później zostały udoskonalone i udzielane pod nazwą wzmocnione ułatwienia dostosowań strukturalnych (Enhanced Structural Adjustment Facility - ESAF) ${ }^{11}$. Zostały one stworzone przez MFW dla państw o niskim dochodzie narodowym. Pomoc ta dotyczyła obniżenia wielkości zadłużenia danego państwa. Zostały one wprowadzone niemal w jednym czasie, przez co różniły się od siebie przede wszystkim skalą i zakresem działań dostosowawczych. Program ESAF wspierał przeprowadzanie głębokich reform polityki makroekonomicznej oraz reformy strukturalne i instytucjonalne. $Z$ kolei by uzyskać pomoc z SAF projekty zmian gospodarczych nie musiały być tak radykalne ${ }^{12}$. Reformy miały pomóc w osiągnięciu szybszego wzrostu gospodarczego i równoważeniu bilansu płatniczego, ale także poprawieniu warunków życia ludności w najuboższych państwach członkowskich oraz ułatwić im zaadoptowanie się do warunków funkcjonowania gospodarki światowej. Konstrukcja ESAF zmuszała do zaangażowania w przeprowadzanie reform w państwie nie tylko jego rząd, ale także instytucje państwowe, działające w nim organizacje i społeczeństwo. Kluczowym warunkiem efektywnego przeprowadzenia reform była również współpraca z Międzynarodowym Bankiem Odbudowy i Rozwoju, regionalnymi bankami rozwoju, donatorami pomocy rozwojowej, doradcami ekonomicznymi oraz prywatnymi inwestorami ${ }^{13}$. Kwalifikacja państw do udziału w ESAF dokonywana była na podstawie ich dochodu narodowego brutto na osobę. Przeprowadzano ją we współpracy z Międzynarodowym Stowarzyszeniem Rozwoju (International Development Association - IDA) - organizacją Grupy Banku Światowego. W ramach 3-letniej umowy kredytobiorca mógł otrzymać nawet 140\% wartości wpłaty udziałowej do kapitału zakładowego MFW. Limit ten mógł być zwiększony do poziomu 185\% w przypadku wystąpienia szczególnych okoliczności. Roczna stopa oprocentowania wynosiła $0,5 \%$, a spłata zaciągniętego kredytu,

${ }^{10}$ J. Landell-Mills, Helping the Poor the IMF's New Facilities for Structural Adjustment, IMF, Washington 1995 , s. 1 .

${ }^{11} \mathrm{~K}$. Czernichowski, Międzynarodowy Fundusz Walutowy wobec wspótczesnych problemów ekonomicznych, w: Rola organizacji międzynarodowych $w$ przezwyciężaniu problemów globalnych, red. J. Rymarczyk, W. Niemiec, Oficyna Wydawnicza Arboretum, Wrocław 2010, s. 46.

12 T. Michałowski, op.cit., s. 194-195.

${ }^{13}$ International Monetary Fund Press Conference on External Evaluation of IMF's Enhanced Structural Adjustment Facility, http://www.imf.org/external/np/tr/1998/TR980313.HTM [dostęp 4.09.2013]. 
w półrocznych ratach, zaczynała się po upływie 5,5 roku i trwała do momentu upływu 10 lat od udostępnienia środków ${ }^{14}$. Środki przeznaczone dla państw najuboższych $\mathrm{w}$ ramach ESAF pochodziły $\mathrm{z}$ wpłat państw członkowskich $\mathrm{w}$ formie dotacji lub darowizn, ale także $z$ inwestycji i depozytów. Były one gromadzone na rachunku ESAF, który był zarządzany przez Fundusz ${ }^{15}$. Od 1996 r. udogodnienie ESAF zaczęło funkcjonować jako stałe narzędzie MFW służące do pomocy ubogim państwom członkowskim. Według wyliczeń MFW w latach 1995-1998 beneficjenci ESAF, którzy zastosowali się do zaleceń Funduszu w kwestii przeprowadzania reform w państwie, odnotowali wzrost DNB per capita z 2,3\% do 2,5\%. Oznaczało to większą zmianę niż $\mathrm{w}$ innych państwach rozwijających się ${ }^{16}$. Przez cały okres funkcjonowania tego udogodnienia podpisano 90 porozumień z 52 państwami na łączną kwotę 10,7 mld dol., czyli 7,6 mld SDR. ESAF istniał do roku $1999^{17}$.

$\mathrm{W}$ drugiej połowie lat 90 . XX w. wzrosło zaangażowanie MFW w tworzenie nowych instrumentów pomocowych dla państw o najniższym poziomie DNB per capita, jak również zwiększyła się wartość środków finansowych przekazywanych przez Fundusz na ten cel (rysunek 1).

Rysunek 1. Rozmiary preferencyjnej pomocy kredytowej MFW w latach 1984-2012 (w mld SDR, ceny bieżące)

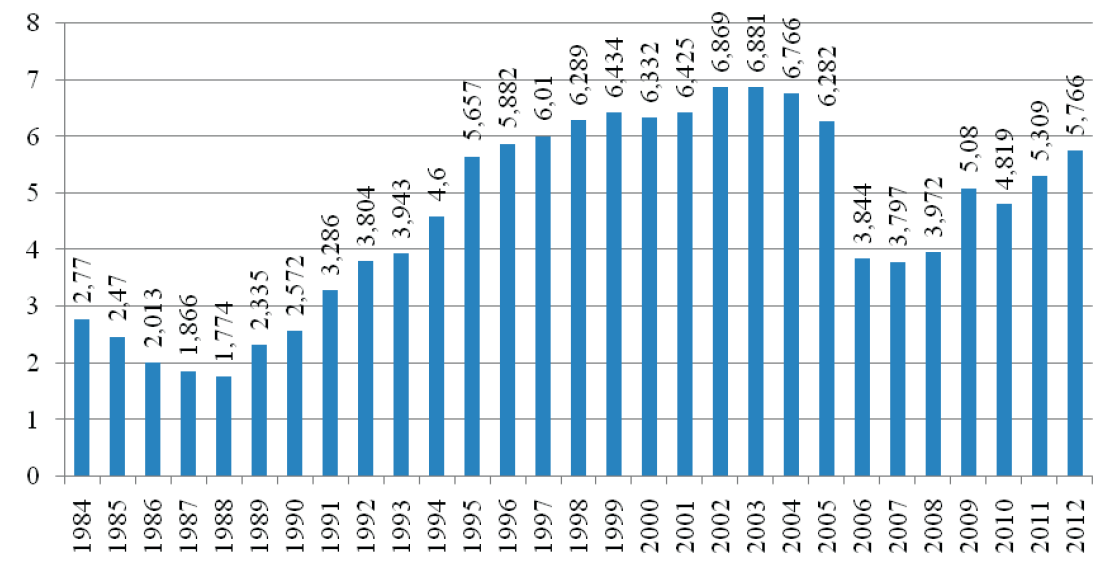

Źródło: Opracowanie własne na podstawie: Total IMF Credit Outstanding for All Members from 1984-2013, http://www.imf.org/external/np/fin/tad/extcred1.aspx [dostęp 6.09.2013].

${ }^{14}$ IMF Concessional Financing Through the ESAF, http://www.imf.org/external/np/exr/facts/esaf.htm [dostęp 5.09.2013].

15 K. Czernichowski, op.cit., s. 46.

16 Overview: Transforming the Enhanced Structural Adjustment Facility (ESAF) and the Debt Initiative for the Heavily Indebted Poor Countries (HIPCs), http://www.imf.org/external/np/esafhipc/1999/ [dostęp 5.09.2013].

17 IMF Lending to Poor Countries - How Does the PRGF Differ From the ESAF?, http://www.imf.org/ external/np/exr/ib/2001/043001.htm [dostęp 5.09.2013]. 
W miejsce scharakteryzowanego udogodnienia ESAF w 1999 r. utworzono nowy instrument - Poverty Reduction and Growth Facility (PRGF), czyli Ułatwienie na rzecz Wzrostu Gospodarczego i Redukcji Ubóstwa. Zostało ono skonstruowane zgodnie z potrzebami państw o najniższych dochodach. Środki udostępniane w ramach tych udogodnień miały wspierać realizację programów ograniczania ubóstwa w poszczególnych państwach członkowskich, ale także stymulować wzrost gospodarczy w najbiedniejszych krajach.

Pomoc udzielana w ramach porozumienia PRGF opierała się na tzw. opracowaniach dotyczących Strategii Ograniczania Ubóstwa (Poverty Reduction Strategy Papers - PRSP). MFW założył, iż potrzeba stworzenia własnego planu rozwoju przez członka w porozumieniu ze społeczeństwem, instytucjami działającymi w kraju oraz przy współpracy z organizacjami międzynarodowymi spowoduje szybszą realizację reform makroekonomicznych. Założono zatem połączenie kwestii redukcji biedy z rozwojem polityki makroekonomicznej. Jednocześnie chroniło to MFW i jego ekspertów przed zarzutami dotyczącymi narzucania państwom nadmiernie rygorystycznych planów reform. Dodatkowym atutem tego rozwiązania było założenie, iż takie dokumenty najlepiej odzwierciedlają priorytety danego państwa członkowskiego, co miało pomóc w stworzeniu najlepszego sposobu walki z ubóstwem i metod osiągnięcia stabilnego wzrostu gospodarczego. Ponadto przyjęto, że przy korzystaniu z pomocy w ramach PRGF MFW zwracać będzie dużą uwagę na zarządzanie środkami publicznymi oraz na ogólne aspekty zarządzania. Takie działania miały za zadanie optymalizację wydatkowania pozyskanych zasobów finansowych oraz uczynienie ich bardziej przejrzystymi. Ważnym aspektem przy pozyskiwaniu środków w ramach PRGF było wykazanie społecznych efektów przeprowadzanych reform $^{18}$. Taka konstrukcja programu pozwoliła MFW na skoncentrowanie się na funkcji doradczej, znacznie ograniczając warunkowość udzielenia pożyczek, gdyż to państwa, na podstawie PRSP, decydowały o otrzymywanej pomocy ${ }^{19}$. Jednocześnie założenia PRSP określały sposoby walki z ubóstwem, które były ${ }^{20}$ :

- prowadzone przez państwo, podkreślając, iż to ono jest autorem danej reformy stworzonej przy współudziale społeczeństwa,

- zorientowane na cel i wyniki,

- korzystne dla najbiedniejszej części społeczeństwa,

- wszechstronne w zidentyfikowaniu wielowymiarowej natury ubóstwa,

\footnotetext{
18 T. Michałowski, op.cit., s. 196.

19 The Poverty Reduction and Growth Facility, http://www.imf.org/external/np/exr/facts/prgf.htm [dostęp 6.09.2013].

${ }^{20}$ Poverty Reduction Strategy Papers, http://www.imf.org/external/np/exr/facts/prsp.htm [dostęp 6.09.2013].
} 
- zorientowane na współpracę, angażując do pomocy rząd, krajowych inwestorów oraz zewnętrznych darczyńców,

- nastawione na długofalowe działanie w celu redukcji ubóstwa.

W programie PRGF zawarte były także wytyczne co do sposobu wykorzystania udzielonych środków finansowych. Za istotne uznawane było zwiększanie wydatków na edukację i opiekę zdrowotną, które z założenia trafiały do najbiedniejszych warstw społeczeństwa oraz wpływały na rozwój gospodarczy państw. Istotne były także wydatki inwestycyjne na tworzenie koniecznej infrastruktury, potrzebnej do rozwoju potencjału ekonomicznego państwa ${ }^{21}$.

By kraj mógł uczestniczyć w programie PRGF, musiał spełniać określone warunki. Najistotniejszym kryterium był dochód narodowy brutto per capita. Jego poziom nie mógł przekraczać progu ustalonego przy kwalifikacji do uzyskania pomocy z Międzynarodowego Stowarzyszenia Rozwoju. Dla przykładu w 2007 r. poziom ten wynosił 1025 dol. na osobę. Wówczas do programu PRGF zakwalifikowano 78 państw ${ }^{22}$. Jednakże ostatecznie nie wszystkie z nich skorzystały z pomocy finansowej.

Oprocentowanie w ramach PRGF wynosiło 0,5\% w skali roku. Spłata kredytu dokonywana była w półrocznych ratach i rozpoczynała się po upływie 5,5 roku od momentu rozpoczęcia kredytowania, a powinna skończyć się wraz z upływem 10 lat. Kwota środków udostępnianych przez Fundusz w ramach 3-letniej umowy nie mogła przekraczać $280 \%$ kwoty udziałowej, jednak w przypadku wystąpienia szczególnych okoliczności limit ten mógł osiągnąć nawet $370 \%{ }^{23}$.

Kredyty preferencyjne udzielane dzięki PRGF były administrowane przez fundusze PRGF-ESF oraz PRGF-HIPC. Rachunek PRGF-ESF składał się z rachunku kredytowego, rezerwowego oraz dotacyjnego. Na rachunku kredytowym znajdowały się środki zgromadzone z pożyczek udzielonych MFW na warunkach rynkowych, od banków centralnych, rządów oraz różnych instytucji państw członkowskich. Środki z tego rachunku zasilały państwa biorące udział w programie PRGF. Rachunek rezerwowy, a raczej środki finansowe na nim zgromadzone były zabezpieczeniem $w$ razie nieterminowej spłaty zaciągniętych kredytów w ramach PRGF. Środki $\mathrm{z}$ tego rachunku używane były także $\mathrm{w}$ razie braku zasobów na rachunku kredytowym, z powodu rozbieżności w spłacie pożyczek udzielonych MFW i spłacie kredytów zaciągniętych $\mathrm{z}$ udogodnienia PRGF. Zasoby zgromadzone na rachunku rezerwowym pokrywały dodatkowo koszty administracyjne ponoszone przy zarządzaniu operacjami programu PRGF. Na rachunek ten wpływały także środki z Rachunku

\footnotetext{
21 Ibidem.

22 T. Michałowski, op.cit., s. 194-196.

23 The Poverty Reduction..., op.cit.
} 
Wydatków Specjalnych MFW. W skład PRGF-ESF wchodził również rachunek dotacyjny. Na nim znajdowały się środki wpłacane w ramach umów bilateralnych między państwem członkowskim a Funduszem oraz środki własne MFW. Różnica między stopą procentową płaconą pożyczkodawcom a stopą, którą płaciły państwa korzystające z programu, finansowana była $\mathrm{z}$ wpłat dokonywanych przez bilateralnych donatorów oraz ze środków własnych MFW. Właśnie na ten cel przeznaczane były środki z rachunku dotacyjnego. Jego nazwa nawiązuje ponadto do formy, jaką przybierały zasoby na nim gromadzone. Były to zazwyczaj dotacje, darowizny, depozyty lub inwestycje złożone na procent niższy od rynkowego ${ }^{24}$. Udogodnienie PRGF działało przez 10 lat. W 2009 r. MFW przeprowadził zmiany w instrumentach preferencyjnych i konstrukcji finansowej, przekształcając PRGF-ESF w PRGT (Poverty Reduction Growth Trust).

W celu lepszego dopasowania programów pomocowych skierowanych na walkę $\mathrm{z}$ ubóstwem do indywidualnych strategii państw zmagających się z tym problemem PRGF w 2009 r. został zastąpiony przez rozszerzone ułatwienie kredytowe (Extended Credit Facility - ECF) ${ }^{25}$. ECF funkcjonuje jako jedno z trzech współczesnych udogodnień na preferencyjnych warunkach pożyczkowych dla państw o niskim dochodzie. Rozszerzone ułatwienie kredytowe udzielane jest wówczas, gdy dane państwo członkowskie boryka się z przedłużającymi się problemami równoważenia bilansu płatniczego. Członkowie mogą skorzystać z tego typu pomocy, jeżeli poprawa zaistniałej sytuacji może dokonać się tylko w średnim lub długim okresie ${ }^{26}$. Cele programu zostały przejęte od PRGF, dotyczą zatem poprawy bilansu płatniczego, trwałego wzrostu gospodarczego oraz zmniejszenia ubóstwa. Nowym wyzwaniem jest udoskonalanie elastyczności pomocy i lepsze dopasowanie jej do potrzeb beneficjenta. Pomoc udzielana jest na 3 do 4 lat $\mathrm{z}$ możliwością ponownego skorzystania $\mathrm{z}$ niej. Wysokość zasobów finansowych udzielanych państwu członkowskiemu zależy od indywidualnej sytuacji ekonomicznej. Nie może ona jednak przekroczyć w jednym roku $100 \%$ wkładu danego państwa do kapitału zakładowego MFW, a łącznie 300\% ${ }^{27}$. Korzystając z udogodnienia ECF, państwa zobowiązują się do urzeczywistniania celów zawartych w ich liście intencyjnym, co powinno stymulować wzrost gospodarczy oraz poprawę sytuacji ekonomicznej państwa. Tak jak w przypadku PRGF, beneficjenci powinni sami określić najważniejsze dla nich cele. ECF pozwala na większą elastyczność wymagań dotyczących dokumentacji przeprowadzanego programu

\footnotetext{
24 T. Michałowski, op.cit., s. 196-197.

${ }^{25}$ Financing the Fund's Concessional Lending to Low-Income Countries, http://www.imf.org/external/np/ exr/ facts/concesslending.htm [dostęp 6.09.2013].

${ }^{26}$ IMF Extended Credit Facility, http://www.imf.org/external/np/exr/facts/ecf.htm [dostęp 8.09.2013].

27 Ibidem.
} 
w ramach PRSP. MFW nadzoruje wdrażanie reform przez obserwacje ekonomicznych danych ilościowych. Są nimi wielkości rezerw międzynarodowych, agregatów monetarnych, równowagi fiskalnej czy zewnętrznych źródeł finansowania. ECF ma na celu zabezpieczenie istotnych wydatków skierowanych m.in. na cele społeczne przez wyznaczanie koniecznych do osiągnięcia limitów ${ }^{28}$. Według stanu z marca 2013 r. z udogodnienia ECF skorzystało 26 państw. Suma środków przeznaczonych na ten cel wyniosła 2,847 mld SDR $^{29}$ (tabela 1 ).

Tabela 1. Wartość dofinansowania w ramach PRGF oraz ECF od 1999 r. do 2013 r. (w mln SDR)

\begin{tabular}{|c|l|c|c|}
\hline Lp. & \multicolumn{1}{|c|}{ Państwo } & PRGF & ECF \\
\hline 1 & Afganistan & 75,35 & 24,00 \\
\hline 2 & Albania & 36,52 & - \\
\hline 3 & Armenia & 93,31 & 106,80 \\
\hline 4 & Azerbejdżan & 54,71 & - \\
\hline 5 & Bangladesz & 316,73 & 182,85 \\
\hline 6 & Benin & 51,77 & 53,06 \\
\hline 7 & Burkina Faso & 116,38 & 75,82 \\
\hline 8 & Burundi & 120,50 & 10,00 \\
\hline 9 & Czad & 46,60 & - \\
\hline 10 & Dżibuti & 35,89 & - \\
\hline 11 & Dominika & 7,69 & - \\
\hline 12 & Etiopia & 100,28 & 9,33 \\
\hline 13 & Gambia & 25,44 & - \\
\hline 14 & Gruzja & 147,50 & - \\
\hline 15 & Ghana & 748,17 & 2,53 \\
\hline 16 & Grenada & 16,38 & 36,72 \\
\hline 17 & Gwinea & 50,18 & 15,12 \\
\hline 18 & Gwinea Bissau & 5,08 & - \\
\hline 19 & Gujana & 54,55 & $36,79,60$ \\
\hline 20 & Haiti & 180,18 & - \\
\hline 21 & Honduras & 155,14 & - \\
\hline 22 & Jemen & 58,50 & - \\
\hline 23 & Kambodża & 98,16 & -60 \\
\hline 24 & Kamerun & & - \\
\hline 25 & Kenia & & - \\
\hline & & & \\
\hline
\end{tabular}

28 Ibidem.

${ }^{29}$ IMF Financial Activities, http://www.imf.org/external/np/tre/activity/2013/030713.htm [dostęp 6.09.2013]. 


\begin{tabular}{|c|c|c|c|}
\hline Lp. & Państwo & PRGF & ECF \\
\hline 26 & Kirgistan & 25,17 & 38,06 \\
\hline 27 & Komory & 10,46 & - \\
\hline 28 & Kongo & 751,44 & - \\
\hline 29 & Laos & 53,31 & - \\
\hline 30 & Lesotho & 24,50 & 39,25 \\
\hline 31 & Liberia & 247,90 & 7,38 \\
\hline 32 & Madagaskar & 144,68 & - \\
\hline 33 & Malawi & 61,46 & 52,93 \\
\hline 34 & Mali & 113,64 & 6,00 \\
\hline 35 & Mauretania & 53,72 & 66,24 \\
\hline 36 & Mołdawia & 115,72 & 170,88 \\
\hline 37 & Mongolia & 12,21 & - \\
\hline 38 & Mozambik & 90,16 & - \\
\hline 39 & Nepal & 49,90 & - \\
\hline 40 & Nikaragua & 175,50 & - \\
\hline 41 & Niger & 98,68 & 22,56 \\
\hline 42 & Pakistan & 861,42 & - \\
\hline 43 & Republika Konga & 32,04 & - \\
\hline 44 & Republika Środkowoafrykańska & 69,62 & 6,96 \\
\hline 45 & Republika Zielonego Przylądka & 8,64 & - \\
\hline 46 & Ruanda & 12,01 & - \\
\hline 47 & Senegal & 24,27 & - \\
\hline 48 & Sierra Leone & 182,72 & 22,20 \\
\hline 49 & Sri Lanka & 38,39 & - \\
\hline 50 & Tadżykistan & 169,40 & - \\
\hline 51 & Tanzania & 154,60 & - \\
\hline 52 & Togo & 95,41 & - \\
\hline 53 & Uganda & 13,50 & - \\
\hline 54 & Wietnam & 124,20 & - \\
\hline 55 & Wybrzeże Kości Słoniowej & 289,43 & 211,38 \\
\hline 56 & Wyspy Salomona & - & 0,15 \\
\hline 57 & Wyspy Świętego Tomasza i Książęca & 5,60 & 0,37 \\
\hline 58 & Zambia & 677,72 & - \\
\hline
\end{tabular}

Źródło: Opracowanie własne na podstawie: IMF Member's Financial Data by Country, http://www.imf.org/ external/np/fin/tad/exfin1.aspx [dostęp 6.09.2013].

W kwietniu 2008 r. MFW wprowadził The Exogenous Shocks Facility - Hight Access Component (ESF-HAC), czyli ułatwienie na wypadek szoków egzogenicznych i udogodnienie łatwego dostępu, które miały za zadanie wspomagać państwa również na warunkach preferencyjnych. Finansowanie było udostępniane w momencie 
wystąpienia problemów ze zrównoważeniem bilansu płatniczego, spowodowanych rozprzestrzenianiem się szoków o charakterze egzogenicznym. Tego rodzaju finansowanie było przyznawane po rozpatrzeniu każdego zgłoszenia w trybie indywidualnym. Maksymalna wysokość dostępnych środków w warunkach normalnych została ustalona na poziomie $150 \%$ kwoty udziałowej członka w MFW. Spłaty dokonywano w okresach półrocznych po 5,5 roku w ciągu 4,5 roku. ESF-HAC nie były oprocentowane ${ }^{30}$.

Udogodnienie ESF-HAC zostało zastąpione w 2011 r. nowym rodzajem kredytu - Standby Credit Facility (SCF). Udogodnienie to zostało stworzone w celu pomocy finansowej państwom o niskim poziomie dochodu narodowego brutto i było częścią reformy, która jest ukierunkowana na wprowadzanie zmian w oferowanych przez Fundusz kredytach w taki sposób, aby były one dużo bardziej elastyczne i możliwe do dostosowania do coraz bardziej zróżnicowanych potrzeb poszczególnych państw zaliczanych do grupy LICs. Środki w ramach SCF są dostępne dla członków mających zrównoważoną sytuację makroekonomiczną, możliwą do utrzymania w dłuższym horyzoncie czasowym, ale istnieje zagrożenie związane z możliwością wystąpienia krótkotrwałych szoków, które mogą spowodować nierównowagę bilansu płatniczego. Program ten ma więc za zadanie m.in. pomoc w utrzymaniu stabilnej sytuacji gospodarczej oraz zapewnieniu wzrostu gospodarczego. Finansowanie SCF jest dostępne dla członków zakwalifikowanych do grupy państw mogących korzystać z pomocy preferencyjnej. Okres trwania umowy kredytowej może wahać się w przedziale od 12 do 24 miesięcy. Limit finansowania w ramach tego programu wynosi 100\% kwoty udziałowej członka rocznie i nie powinien przekraczać 300\% kwoty w całym okresie kredytowania. Państwa korzystające z SCF zobowiązane są do wprowadzenia reform, które pozwolą osiągnąć stabilną pozycję makroekonomiczną w krótkim okresie. Stopa oprocentowania środków zaangażowanych w program SCF wynosi 0,25\%. Okres karencji został w tym przypadku ustalony na 4 lata, a maksymalny termin dokonania spłaty kredytu na 8 lat. Prowizja od dostępności kredytu jest zwiększana o 0,15\% w skali roku i naliczana od niewykorzystanej części kwoty udostępnianej przez Fundusz w ciągu każdego 6-miesięcznego okresu kredytowania ${ }^{31}$.

Kolejnym rodzajem preferencyjnej pomocy finansowej, z której mogą obecnie skorzystać słabo rozwinięte państwa członkowskie MFW, jest Rapid Credit Facility (RCF), czyli mechanizm kredytowy szybkiego reagowania. Udogodnienie to ma na celu zoptymalizowanie pomocy udzielanej w nagłych wypadkach. Zastąpiło

30 The Exogenous Shocks Facility - High Access Component, http://www.imf.org/external/np/exr/facts/ esf.htm [dostęp 6.09.2013].

${ }^{31}$ IMF Standby Credit Facility, http://www.imf.org/external/np/exr/facts/scf.htm [dostęp 6.09.2013]. 
ono ESF-HAC oraz program pomocy udzielanej w przypadku wystąpienia klęsk żywiołowych oraz w celu łagodzenia skutków konfliktów zbrojnych. W porównaniu z programami, które były oferowane wcześniej przez MFW, koszt RCF jest niższy. Program ten jest skierowany do najuboższych członków, których dotknęły nagłe problemy związane z równoważeniem bilansu płatniczego, a kompleksowy program naprawczy oferowany przez MFW jest niepotrzebny lub niemożliwy do zrealizowania. Środki finansowe udostępniane są w postaci jednorazowej wypłaty całkowitej kwoty kredytu. Warto zaznaczyć, że powtórzenie takiej wypłaty, nawet kilkakrotne, jest możliwe, jeżeli nierównowaga bilansu płatniczego spowodowana jest szokami zewnętrznymi. Zazwyczaj limit środków ustalany jest na poziomie $25 \%$ kwoty udziałowej państwa członkowskiego do wykorzystania w ciągu roku oraz 75\% w całym okresie finansowania. W szczególnych przypadkach mogą zostać one zwiększone odpowiednio do 50\% i 100\% kwoty. Należy wspomnieć, że w 2013 r. środki udzielane w ramach RCF nie są oprocentowane, okres karencji wynosi 5,5 roku, a zwrot kredytu powinien nastąpić maksymalnie w ciągu 10 lat od momentu udostępnienia środków. Warto również dodać, że Fundusz dokonuje rewizji oprocentowania wszystkich kredytów preferencyjnych raz na 2 lata ${ }^{32}$.

W ciągu istnienia Międzynarodowego Funduszu Walutowego oferowane programy preferencyjnej pomocy finansowej często się zmieniały. Pomoc stawiana do dyspozycji członkom przez Fundusz zawsze jednak była nakierowana na przezwyciężanie przez poszczególne państwa problemów dotyczących bilansu płatniczego, poprawienie sytuacji ekonomicznej oraz zapewnienie im warunków stabilnego i zrównoważonego rozwoju, zarówno gospodarczego, jak i społecznego. Należy również zaznaczyć, że reformy, które wprowadzał Fundusz w ostatnich latach, mają przede wszystkim na celu nie tylko zwiększenie zdolności MFW do przeciwdziałania kryzysom oraz do szybkiego łagodzenia skutków ich wystąpienia, ale również realizacji strategii ograniczania ubóstwa i zrównoważonego rozwoju. Dążenie do osiągnięcia tych celów przejawia się m.in. w coraz częstszym przyznawaniu potrzebującym państwom kredytowania w kwocie wyższej niż wynikałoby to z ustalonego limitu (tzw. exceptional access) oraz podejmowaniu kroków zapobiegawczych, czyli korzystaniu $z$ oferowanych kredytów typu precautionary. Dodatkowo nastąpiły także zmiany związane z warunkami stawianymi kredytobiorcom przez MFW, zwłaszcza w postaci braku oprocentowania preferencyjnych kredytów, czy utworzeniem nowych elastycznych preferencyjnych instrumentów finansowych ${ }^{33}$.

\footnotetext{
${ }^{32}$ Rapid Credit Facility, http://www.imf.org/external/np/exr/facts/rcf.htm [dostęp 8.09.2013].

${ }^{33} \mathrm{~K}$. Edwards, W. Hsieh, Recent Changes in IMF Lending, „Bulletin of Reserve Bank of Australia” December Quarter 2011, s. 79.
} 
Zakres współczesnej pomocy kredytowej (stan na 1 września 2013 r.) przeznaczanej dla państw o najniższych dochodach udzielanych na zasadach preferencyjnych obejmuje zatem ${ }^{34}$ :

- rozszerzone ułatwienie kredytowe (Extended Credit Facility - ECF),

- rezerwowy mechanizm kredytowy (Standby Credit Facility - SCF),

- mechanizm kredytowy szybkiego reagowania (Rapid Credit Facility - RCF).

\section{Współpraca MFW i MBOiR na rzecz redukcji zadłużenia zewnętrznego państw najbiedniejszych}

Przyczyniając się do realizacji strategii zrównoważonego rozwoju, MFW w 1996 r. podjął współpracę z Międzynarodowym Bankiem Odbudowy i Rozwoju. Wówczas podczas szczytu G7 w Lyonie, we Francji, podjęto decyzję w sprawie zrównoważenia obciążeń zadłużeniowych państw najuboższych w ramach Inicjatywy HIPC (Heavily Indebted Poor Countries). Miała ona na celu zmniejszenie długu zewnętrznego państw najbiedniejszych do takiego poziomu, przy którym poradzą sobie one z dalszą jego obsługą, jak również będą w stanie zdynamizować reformy gospodarcze, społeczne i polityczne w celu zwiększenia wzrostu gospodarczego i obniżenia skali ubóstwa ${ }^{35}$.

Redukcja zadłużenia miała polegać na zlikwidowaniu tzw. nawisu zadłużenia (debt overhang), który oznacza zbyt duży dług zniechęcający inwestorów do lokowania swoich środków finansowych w danym państwie. Nadmierne zadłużenie sprowadza się bowiem do przewidywanej podwyżki podatków mającej na celu spłatę kredytów przez państwo. Nawis stanowi sumę przekraczającą tolerowaną wartość, czyli możliwości państwa do obsługi swojego zadłużenia. Likwidacja nadmiernego długu jest korzystna dla państwa i jego wierzycieli, gdyż stanowi większą gwarancję spłaty długu ${ }^{36}$.

Z kolei redukcja ubóstwa w ramach inicjatywy miała polegać na przesunięciu środków niezbędnych dotąd do obsługi długu na finansowanie celów społecznych, takich jak zwalczanie skutków klęsk żywiołowych, wyżywienie i zwiększenie produk-

\footnotetext{
${ }^{34}$ IMF Lending, http://www.imf.org/external/np/exr/facts/howlend.htm [dostęp 6.09.2013].

35 P. Bagiński, M. Kowalska, Finansowanie rozwoju krajów słabiej rozwiniętych jako element polityki zagranicznej państw rozwiniętych, w: Pomoc rozwojowa dla krajów rozwijajacych się na przełomie XX i XXI wieku, red. E. Latoszek, Dom Wydawniczy Elipsa, Warszawa 2010, s. 130.

${ }^{36}$ K. Czernichowski, op.cit., s. 47.
} 
cji rolnej, udzielanie mikrokredytów na działalność gospodarczą, poprawa systemu rent i emerytur, służba zdrowia czy edukacja ${ }^{37}$.

Zazwyczaj w państwach ubogich nie znajdowano środków finansowych na walkę z problemami społecznymi, gdyż w pierwszej kolejności były one przeznaczane na spłatę kredytów. Przykładem takich działań może być Etiopia, która na spłatę długów w latach 90 . XX w. przeznaczała nawet $47 \%$ swoich przychodów z eksportu. Wówczas w Etiopii tylko jedno z 5 dzieci rozpoczynało naukę w szkole, a tylko jeden z 4 obywateli miał dostęp do wody pitnej. Z kolei w Mozambiku zamierzano wprowadzić powszechną edukację wczesnoszkolną, lecz reformę przesunięto o 10 lat, gdyż państwo w pierwszej kolejności zmuszone było zająć się spłatą odsetek od zobowiązań. W Malawi kwota wydana na obsługę długu znacząco przewyższała łączne środki na opiekę zdrowotną oraz edukację. Z kolei zadłużenie zagraniczne Tanzanii per capita w latach 90. XX w. wynosiło dwukrotność dochodu na osobę ${ }^{38}$.

Proces ubiegania się o otrzymanie pomocy w ramach inicjatywy HIPC przebiegał dwuetapowo. W ramach pierwszego etapu państwa miały obowiązek spełnić cztery główne wymogi ${ }^{39}$ :

- być uprawnionym do zaciągania preferencyjnych kredytów z IDA oraz MFW,

- zmierzać się z długiem niemożliwym do spłaty bez pomocy z zewnątrz,

- stworzyć listę reform gospodarczych zgodnie z wytycznymi MFW i Międzynarodowego Banku Odbudowy i Rozwoju,

- utworzyć PRSP, stosując się do zaleceń Funduszu.

Kiedy członek spełnił powyższe warunki lub znacząco zbliżył się do ich spełnienia, MFW w porozumieniu z MBOiR podejmował decyzję o zakwalifikowaniu państwa do Inicjatywy HIPC, czyli dochodził do etapu zwanego punktem decyzyjnym. Po jego osiągnięciu państwo członkowskie mogło otrzymać natychmiastową, aczkolwiek tymczasową pomoc na obsługę długu ${ }^{40}$.

Aby jednak osiągnąć dalszą redukcję zadłużenia, państwo powinno było przejść do drugiego kroku, czyli tzw. punktu zakończenia, w którym zobligowane było do spełnienia następujących warunków ${ }^{41}$ :

- ustanowienia dalszej listy celów do osiągnięcia w związku z programami pomocowymi MFW i MBOiR,

\footnotetext{
${ }^{37}$ M. Dębska, Bank Światowy. Działalność pożyczkowa, Wydawnictwo WSCiL, Warszawa 2010, s. 103.

${ }^{38}$ K. Czernichowski, op.cit., s. 48.

${ }^{39}$ Ibidem.

40 Ibidem.

${ }^{41}$ Ibidem.
} 
- wcielenia w życie kluczowych reform uzgodnionych w pierwszej fazie programu,

- przyjęcia i wdrożenia PRSP przez przynajmniej rok.

Już po 2 latach funkcjonowania Inicjatywa HIPC zaczęła być krytykowana, głównie z powodu małego zmniejszania ciężaru zadłużenia, długiego czasu trwania procesu jego redukcji oraz zbyt wymagających kryteriów kwalifikacji państw do programu ${ }^{42}$. Dlatego też w 1999 r. na szczycie G7 w Kolonii, w Niemczech HIPC została zmieniona na Wzmocnioną Inicjatywę HIPC. Początkowo miała ona trwać 2 lata, w rzeczywistości jednak była czterokrotnie przedłużana. Jej zadaniem jest szybsze przeprowadzanie procesu oddłużania, a także pomoc większej liczbie państw oraz wzmocnienie oddziaływania między redukcją zadłużenia a likwidacją ubóstwa i zmianami w polityce społecznej państw ${ }^{43}$. Inicjatywa ta obejmuje zatem wiele wymiarów: umarzanie długów, reformę polityki strukturalnej i społecznej z naciskiem zwłaszcza na usługi w zakresie zdrowia i edukacji na poziomie podstawowym. W programie mogą brać udział wszyscy wierzyciele: dwustronni, wielostronni i handlowi, którzy ją finansowali ${ }^{44}$.

Wzmocniona Inicjatywa zakłada zamiast sztywnych - płynne punkty docelowe redukcji zadłużenia, które są uzależnione od uzyskanych postępów w reformach. Kraj może uzyskać redukcję zadłużenia wcześniej, tzn. przed uzyskaniem wielkości docelowych. Poziom redukcji zadłużenia jest bowiem uzależniony od faktycznego postępu, a nie od przewidywanych osiągnięć.

Mechanizm przyznawania pomocy w ramach Wzmocnionej Inicjatywy HIPC jest - w porównaniu z poprzednią - bardziej czytelny i obejmuje również dwa etapy. $\mathrm{W}$ ramach pierwszego etapu - podobnie jak w poprzedniej inicjatywie - kraje w okresie 3 lat przygotowują się do osiągnięcia punktu decyzyjnego przez opracowanie strategii redukcji ubóstwa. W trakcie drugiego etapu państwa stosują politykę określoną w punkcie decyzyjnym, aby osiągnąć docelowy punkt płynny. MBOiR i MFW dostarczają przejściową pomoc, Klub Paryski dokonuje restrukturyzacji zadłużenia zgodnie $\mathrm{z}$ warunkami z Kolonii ${ }^{45}$, a pozostali wierzyciele przyznają przejściową redukcję długu na podobnych warunkach, popierając globalną strategię redukcji biedy. Punkt docelowy płynny jest związany z prowadzeniem przez co najmniej rok globalnej stra-

\footnotetext{
42 Ibidem, s. 48.

${ }^{43}$ Debt Relief Under the Heavily Indebted Poor Countries (HIPC) Initiative, http://www.imf.org/external/ $\mathrm{np} / \mathrm{exr} /$ facts/hipc.htm [dostęp 8.09.2013].

${ }^{44}$ Inicjatywa na rzecz głęboko zadłużonych krajów ubogich (HIPC), http://europa.eu/legislation_summaries/development/least_developed_countries/r12402_pl.htm [dostęp 8.09.2013].

${ }_{45}$ Redukcja 90\% lub więcej wartości zaktualizowanej netto zadłużenia.
} 
tegii redukcji biedy, a szczególnie polityki stabilizacji i dostosowań strukturalnych. Wszyscy wierzyciele dostarczają pomoc określoną w punkcie decyzyjnym. Ta pomoc nie jest poddawana żadnym dodatkowym uwarunkowaniom. Tak więc:

- Klub Paryski przyznaje redukcję zadłużenia na warunkach z Kolonii,

- pozostali wierzyciele bilateralni i handlowi przyznają co najmniej taką samą redukcję zadłużenia,

- organizacje międzynarodowe przyznają redukcję zadłużenia zgodnie z wybraną opcją ${ }^{46}$.

Inicjatywa finansowana jest w 45\% ze środków MFW i innych instytucji międzynarodowych, takich jak MBOiR, Afrykański Bank Rozwoju, Międzyamerykański Bank Rozwoju, Klub Paryski. Pozostała część pochodzi od wierzycieli państw uczestniczących w programie. Całkowity koszt dla wierzycieli, oszacowany dla 39 państw, to $76 \mathrm{mld}$ dol. Zasoby udostępniane przez Fundusz to środki finansowe z wkładów członkowskich do kapitału zakładowego i sprzedaży złota z 1999 r., które według stanu z kwietnia $2012 \mathrm{r}$. wyniosły $2,5 \mathrm{mld} \mathrm{SDR}^{47}$. Dla MFW łączne koszty tej Inicjatywy oszacowano na około 6,5 mld dol. Według danych z końca $2012 \mathrm{r}$. dotychczasowe wydatki poniesione przez Fundusz w związku z pomocą w ramach Inicjatywy HIPC dla państw, które przeszły przez cały proces oddłużania, wyniosły 4,527 mld dol., co stanowiło $16 \%$ całkowitych kosztów poniesionych przez wszystkich wierzycieli ${ }^{48}$. Według stanu z marca 2013 r. 35 państw członkowskich dotarło do punktu zakończenia realizacji pomocy oddłużeniowej, co oznacza całkowitą redukcję ich zadłużenia przez MFW i innych wierzycieli. Czad spełnił tylko wymagania pierwszej fazy całego procesu oddłużania, przez co mógł korzystać wyłącznie z tymczasowej pomocy. Dodatkowo trzy państwa - Erytrea, Somalia i Sudan zostały ocenione jako potencjalni beneficjenci Inicjatywy HIPC, ale nie osiągnęły jeszcze pierwszego etapu w procesie redukcji zadłużenia ${ }^{49}$.

W 2005 r. państwa zrzeszone w ramach grupy G8 złożyły Międzynarodowemu Funduszowi Walutowemu, Międzynarodowemu Stowarzyszeniu Rozwoju oraz Afrykańskiemu Funduszowi Rozwoju propozycję pomocy dla państw rozwijających się na większą skalę niż przewiduje to Wzmocniona Inicjatywa HIPC. Zaproponowały one bowiem stworzenie nowego programu na rzecz redukcji zadłużenia, nadając mu nazwę Inicjatywy Wielostronnej Redukcji Zadłużenia (Multilateral Debt

46 E. Chrabonszczewska, Międzynarodowe organizacje finansowe, Oficyna Wydawnicza SGH, Warszawa 2005, s. 355-356.

47 IMF Annual Report 2012, IMF, Washington 2012, s. 37.

${ }^{48}$ Heavily Indebted Poor Countries (HIPC) Initiative and Multilateral Debt Relief Initiative (MDRI) - Statistical Update, IMF, Washington 2013, s. 26.

49 Debt Relief..., op.cit. 
Relief Initiative - MDRI). Celem programu jest całkowita likwidacja długu państw, a przez to uwolnienie zasobów finansowych, które pomogą im w osiągnięciu Milenijnych Celów Rozwoju. Całkowitego umorzenia miały dokonywać wyłącznie trzy organizacje, nie angażując pozostałych wierzycieli. Jednak już w 2007 r. do Inicjatywy dołączył Międzyamerykański Bank Rozwoju, deklarując redukcję długu pięciu państwom ${ }^{50}$.

Pomoc w ramach MDRI przeznaczona jest dla państw, które osiągnęły już tzw. punkt końcowy w ramach Inicjatywy HIPC lub miały DNB per capita na poziomie niższym niż 380 dol. i jednocześnie niespłacone zobowiązania wobec Funduszu na koniec roku $2004^{51}$.

Aby zakwalifikować się do pomocy w ramach MDRI, MFW wymaga udokumentowania satysfakcjonujących Fundusz osiągnięć $w^{52}$ :

- polityce makroekonomicznej,

- wdrażaniu strategii redukcji ubóstwa,

- zarządzania wydatkami publicznymi.

Decyzja o przyznaniu państwu środków z MDRI jest podejmowana osobno przez każdą organizację. Także sposób realizacji oddłużania może się różnić. Całkowity koszt dla czterech wierzycieli został oszacowany na 36,9 mld dol. MFW w związku z MDRI poniesie wydatki w wysokości około 4,2 mld dol. W 2012 r. wyniosły one 2,3 mld SDR ${ }^{53}$. Pomoc skierowana została do 35 państw biorących udział w Inicjatywie HIPC oraz do Kambodży i Tadżykistanu, które zostały objęte Inicjatywą MDRI przez wypełnienie drugiego kryterium kwalifikacyjnego $0^{54}$ (tabela 2).

Tabela 2. Koszty poniesione przez MFW w związku z inicjatywami HIPC i MDRI (w mln dol.)

\begin{tabular}{|l|c|c|}
\hline \multicolumn{1}{|c|}{ Państwo } & $\begin{array}{c}\text { Inicjatywa HIPC } \\
\text { (w latach 1998-2012) }\end{array}$ & $\begin{array}{c}\text { Inicjatywa MDRI } \\
\text { (w latach 2006-2012) }\end{array}$ \\
\hline Benin & 28,2 & 49,3 \\
\hline Boliwia & 96,7 & 223,7 \\
\hline Burkina Faso & 68,3 & 82,4 \\
\hline Burundi & 33,3 & 13,4 \\
\hline Czad & 11,9 & - \\
\hline
\end{tabular}

50 The Multilateral Debt Initiative, http://www.imf.org/external/np/exr/facts/mdri.htm [dostęp 8.09.2013].

${ }^{51}$ M. Dębska, Działania Banku Światowego i Międzynarodowego Funduszu Walutowego na rzecz najbiedniejszych państw zadtużonych, „Zeszyty Naukowe WSCiL” 2010, nr 26, s. 69.

${ }_{52}$ The Multilateral Debt Initiative, op.cit.

${ }^{53}$ IMF Annual Report 2012, op.cit., s. 37.

${ }^{54}$ Heavily Indebted..., op.cit., s. 9. 


\begin{tabular}{|c|c|c|}
\hline Państwo & $\begin{array}{c}\text { Inicjatywa HIPC } \\
\text { (w latach 1998-2012) }\end{array}$ & $\begin{array}{c}\text { Inicjatywa MDRI } \\
\text { (w latach 2006-2012) }\end{array}$ \\
\hline Demokratyczna Republika Konga & 495,2 & - \\
\hline Etiopia & 69,2 & 115,1 \\
\hline Gambia & 3,6 & 11,6 \\
\hline Ghana & 139,9 & 317,9 \\
\hline Gujana & 88,0 & 45,6 \\
\hline Gwinea & 53,6 & - \\
\hline Gwinea Bissau & 14,3 & - \\
\hline Haiti & 3,6 & - \\
\hline Honduras & 38,5 & 141,9 \\
\hline Kambodża & - & 82,1 \\
\hline Kamerun & 49,0 & 219,4 \\
\hline Komory & 4,6 & - \\
\hline Kongo & 9,7 & 7,5 \\
\hline Liberia & 670,3 & 177,3 \\
\hline Madagaskar & 24,1 & 185,6 \\
\hline Malawi & 54,8 & 21,6 \\
\hline Mali & 72,5 & 90,2 \\
\hline Mauretania & 54,2 & 44,5 \\
\hline Mozambik & 163,4 & 120,0 \\
\hline Nikaragua & 108,1 & 132,6 \\
\hline Niger & 50,6 & 86,4 \\
\hline Republika Środkowoafrykańska & 28,1 & 2,9 \\
\hline Ruanda & 73,6 & 29,1 \\
\hline Senegal & 55,7 & 136,9 \\
\hline Sierra Leone & 152,9 & 115,2 \\
\hline Tadżykistan & - & 100,1 \\
\hline Tanzania & 139,8 & 299,0 \\
\hline Togo & 0,3 & - \\
\hline Uganda & 182,8 & 109,6 \\
\hline Wybrzeże Kości Słoniowej & 40,4 & - \\
\hline Wyspy Świętego Tomasza i Książęca & 1,4 & 1,6 \\
\hline Zambia & 728,4 & 575,7 \\
\hline Łącznie & 3806,2 & 3538,3 \\
\hline
\end{tabular}

Źródło: Heavily Indebted Poor Countries (HIPC) Initiative and Multilateral Debt Relief Initiative (MDRI) - Statistical Update, IMF, Washington 2013, s. 31-32. 


\section{Pomoc techniczna i nadzór MFW dla państw LICs}

Jak już wspominano, MFW oprócz pomocy stricte finansowej zapewnia także państwom członkowskim grupy LICs pomoc techniczną oraz sprawuje nadzór nad systemem finansowym.

Międzynarodowy Fundusz Walutowy świadczy pomoc techniczną zwłaszcza w zakresie: zarządzania dochodami i wydatkami publicznymi, działalności bankowej, stabilności sektora finansowego, systemów kursowych, statystyk gospodarczych i finansowych oraz problemów prawnych. Pomoc ta jest najczęściej oferowana nieodpłatnie ${ }^{55}$.

Pomoc techniczna przejawia się w systematycznej organizacji i prowadzeniu szkoleń oraz kursów tematycznych dla administracji poszczególnych państw członkowskich. Tego rodzaju treningi, prowadzone w Waszyngtonie przez Instytut MFW (IMF Institute) oraz w innych jego regionalnych agendach (w Austrii, Brazylii, Chinach, Indiach, Singapurze, Tunezji i Zjednoczonych Emiratach Arabskich), mają na celu wzmocnienie zaplecza merytorycznego instytucji wewnętrznych, a tym samym usprawnienie procesu zarządzania gospodarką i finansami publicznymi na szczeblu krajowym $^{56}$.

Wsparcie techniczne obejmuje również pomoc doradczą i konsultacyjną w zakresie prowadzenia polityki ekonomicznej. MFW promuje implementację właściwych standardów, procedur i tzw. dobrych praktyk w zarządzaniu gospodarką oraz związanymi z nią instytucjami regulacyjnymi. W szczególności odnoszą się one do trzech zasadniczych sfer: konieczności zachowania transparentności w prowadzonej polityce gospodarczej oraz w przygotowaniu i prezentacji niezbędnych danych statystycznych (sfera I), prowadzenia skutecznego nadzoru nad całym sektorem finansowym danego kraju (sfera II) i wdrożenia jasnych reguł działalności biznesowej na poziomie mikroekonomicznym (sfera III) ${ }^{57}$.

W ostatnich latach Fundusz zwiększył środki finansowe oraz osobowe przeznaczane na pomoc techniczną. Ponad $80 \%$ środków na pomoc techniczną jest wydatkowanych w krajach o niskim poziomie rozwoju gospodarczego. MFW współpracuje również z donatorami pomocy rozwojowej, którym udziela wsparcia merytorycznego

55 E. Chrabonszczewska, Międzynarodowy Fundusz Walutowy, w: Kompendium wiedzy o organizacjach międzynarodowych, red. E. Łaźniewska, P. Deszczyński, Wydawnictwo Naukowe PWN, Warszawa 2011, s. 226.

${ }_{56}$ M. Wróblewski, Międzynarodowy Fundusz Walutowy i Bank Światowy wobec kryzysów finansowych, w: Kompendium wiedzy o organizacjach międzynarodowych, red. E. Łaźniewska, P. Deszczyński, Wydawnictwo Naukowe PWN, Warszawa 2011, s. 262.

${ }^{57}$ Ibidem. 
dotyczącego sytuacji makroekonomicznej w państwach biorcach i pomaga im efektywnie kierować strumienie środków finansowych, by jak najlepiej wypełniać zalecenia MFW dla danego państwa ${ }^{58}$. Jednocześnie MFW dużą wagę przykłada do uczynienia z pomocy technicznej instrumentu wzrostu skuteczności nadzoru oraz realizowanych programów dostosowawczych. Takie inicjatywy, jak program oceny sektora finansowego, stosowanie norm międzynarodowych, inicjatywy na rzecz krajów najbiedniejszych i najbardziej zadłużonych, walka z finansowaniem terroryzmu wzmagają popyt na pomoc techniczną.

Monitorowanie polityki gospodarczej i finansowej państw członkowskich stanowi także istotny element działalności MFW. Gdy dany kraj staje się członkiem MFW, wyraża zgodę nie tylko na poddanie swojej polityki międzynarodowej obserwacji, ale zobowiązuje się także do jej prowadzenia według określonych zasad. Należą do nich przede wszystkim: osiąganie uporządkowanego wzrostu gospodarczego, prowadzenie polityki niskiej inflacji, unikanie manipulowania kursem walutowym i dostarczenie MFW określonych informacji o gospodarce krajowej. Analiza sytuacji poszczególnych krajów jest prowadzona na podstawie odpowiednio sporządzanych danych statystycznych oraz sprawozdań i dlatego MFW dużą wagę przykłada do jakości i terminowości danych dostarczanych przez członków. Są to dane dotyczące stanu rezerw walutowych, zadłużenia zagranicznego, przepływów kapitałowych, pozwalające na określenie wrażliwości zewnętrznej danego kraju ${ }^{59}$.

Podstawowym instrumentem służącym do realizacji obowiązku nadzoru przez Fundusz są tzw. konsultacje. Misje MFW odwiedzają dany kraj i sporządzają raporty dotyczące sytuacji ekonomicznej dla Rady Administracyjnej MFW, która może wystosować zalecenia dla danego państwa. Przeglądowi podlegają polityka kursowa, monetarna, fiskalna, strukturalna, uregulowania dotyczące funkcjonowania sektora finansowego oraz sprawy instytucjonalne, jak np. niezależność banku centralnego.

W celu zwiększenia efektywności nadzoru prowadzonego przez MFW w $2008 \mathrm{r}$. na kolejne lata Fundusz wyodrębnił priorytety ekonomiczne i operacyjne. W obszarze priorytetów ekonomicznych wyznaczył cztery cele: rozwiązywanie kryzysów na rynkach finansowych, wzmocnienie globalnego systemu finansowego, wyrównanie gwałtownych zmian cen surowców, popieranie uporządkowanego zmniejszania globalnej nierównowagi. W ramach priorytetów operacyjnych MFW sformułował również cztery cele; są nimi: ocena ryzyka, nadzór nad sektorem finansowym i powiązaniami realno-finansowymi, perspektywa wielostronna, analiza kursu walutowego i ryzyka stabilności zewnętrznej.

${ }^{58}$ Technical Assistance, http://www.imf.org/external/about/techasst.htm [dostęp 6.09.2013].

${ }^{59}$ E. Chrabonszczewska, Międzynarodowy Fundusz Walutowy, op.cit., s. 224. 
W trakcie procesu nadzoru Fundusz wskazuje potencjalne zagrożenia dla stabilności i wzrostu gospodarczego oraz doradza członkom niezbędne dostosowania ${ }^{60}$. Zasadniczym celem nadzoru jest promowanie współpracy walutowej i stabilności finansowej oraz ekspansja wymiany handlowej, a tym samym wspieranie zrównoważonego rozwoju.

\section{Wnioski}

Teorie wpływu polityki makroekonomicznej i rozwoju państwa na skalę redukcji ubóstwa oraz praktyka potwierdzają, iż zmiana jednego wskaźnika ekonomicznego ma wpływ na pozostałe. Istnieje zatem bezpośrednia zależność między wzrostem gospodarczym a zwiększaniem się dochodów wśród najuboższej warstwy społecznej. W państwach rozwijających się bardzo istotne dla polityki rozwoju jest także dobre zarządzanie. Gdy działa ono w niewłaściwy sposób, wydatki na cele rozwoju społecznego są mało efektywne, a wzrost gospodarczy państwa jest średnio niższy o 1,6\%. Z kolei spadek inflacji o 10 pkt. proc. może przełożyć się na wzrost gospodarczy aż o 0,5 pkt. proc. Podobny wynik można zaobserwować przy zmniejszeniu deficytu budżetowego o 1 pkt. proc. DNB ${ }^{61}$. Zatem stabilność makroekonomiczna i wzrost gospodarczy zależą zarówno od czynników strukturalnych, jak i instytucjonalnych.

Wyniki przytoczonych badań wpłynęły na strategię MFW wobec najuboższych członków. W celu redukcji ubóstwa Fundusz przeznacza coraz więcej środków finansowych na ich rozwój gospodarczy przez walkę z inflacją czy redukcję deficytów płatniczych i zadłużenia. Spowodowały one także wzmożenie prac organizacji nad nowymi zasadami pomocy najbiedniejszym państwom członkowskim. Reformy instrumentów kredytowych miały na celu umożliwienie lepszego uwzględnienia zróżnicowanych potrzeb państw członkowskich zwłaszcza o niskim dochodzie per capita. Aby spełnić wciąż rosnące potrzeby finansowe, MFW znacznie wzmocnił również swoją zdolność kredytową ${ }^{62}$. Zaczął zatem przekształcać się w organizację, która nie tylko stawia do dyspozycji środki finansowe i służy pomocą techniczną członkom

${ }^{60}$ IMF Annual Report 2009, s. 65, http://www.imf.org/external/pubs/ft/ar/2009/eng/pdf/ar09_eng.pdf [dostęp 8.09.2013].

${ }^{61}$ D. Lombardi, IMF Working Paper, The IMF's Role in Low-Income Countries: Issues and Challenges, IMF, Washington 2005, s. 10-11.

${ }^{62}$ N. Shafik, Rethinking Sustainable Development, http://www.imf.org/external/pubs/ft/fandd /2012/12/ straight.htm [dostęp 8.09.2013]. 
zmierzającym się z problemami bilansu płatniczego, ale również tym, którzy zmagają się z problemami społecznymi i rozwojowymi, a zwłaszcza z ubóstwem.

Współpraca między Bankiem Światowym i MFW w ramach inicjatyw oddłużeniowych, pomoc techniczna i nadzór Funduszu przyczyniają się do wzrostu efektywności reform gospodarczych przeprowadzanych w państwach członkowskich oraz realizowanych programów dostosowawczych i rozwojowych ${ }^{63}$, a także pobudzają zdolności instytucjonalne państw członkowskich w dziedzinie prowadzenia polityki gospodarczej. MFW promuje przy tych działaniach należyte zarządzanie gospodarcze i finansowe, co jest ważnym wkładem MFW w strategię zrównoważonego rozwoju.

\section{IMF initiatives for sustained development of its member states}

The aim of this paper is to analyze the activities of IMF concerning implementation of sustainable development strategies, and in particular to examine evolution of its preferential assistance, present IMF's initiatives related to reduction of external debt of states with particular emphasis on cooperation with the World Bank in debt relief initiatives and its technical and supervisory activities.

Keywords: International Monetary Fund (IMF), sustainable development, International Bank for Reconstruction and Development (IBRD), preferential credit assistance, debt relief, technical assistance, supervision

\section{Les activités du Fonds monétaire international pour le développement durable de ses états membres}

Le but de cette étude est d'analyser les activités du FMI concernant la mise en œuvre des stratégies de développement durable et en particulier d'examiner lévolution de son aide préférentiel, de présenter ses initiatives en matière de réduction de la dette extérieure de ses états membres avec un accent mis sur la coopération avec la Banque mondiale dans le cadres des initiatives d'allégement de la dette et de ses activités techniques et de surveillance.

${ }^{63}$ IMF's Response to the Global Economic Crisis, s. 53, https://www.imf.org/external/np/exr/facts/changing.html [dostęp 8.09.2013]. 
Mots-clés: Fonds monétaire international (FMI), le développement durable, la Banque internationale pour la reconstruction et le développement (BIRD), l'aide au crédit préférentiel, l'allégement de la dette, l'assistance technique, la supervision

\section{Деятельность Международного валютного фонда по содействию устойчивому развитию государств-членов}

Вовлечение Международного валютного фонда в стратегию устойчивого развития становится заметным только с середины 90-х годов XX века. Основными направлениями деятельности Фонда, связанными с реализацией этой стратегии, являются: кредитная помощь (прежде всего льготная), облегчение бремени задолженности, техническая помощь, а также контроль за курсовой политикой и финансовой системой государств-членов.

Цель данного исследования состоит в анализе деятельности МВФ, касающиеся осуществления стратегии устойчивого развития, и особенно эволюции льготной помощи. Внимание уделяется также принимаемым Фондом мерам по сокращению внешнего долга стран, подчеркивая его сотрудничество со Всемирным банком в рамках инициатив по облегчению бремени задолженности и его технической и надзорной деятельности.

МВФ выделяет все больше средств для экономического развития беднейших членов; активизировал работу по новым правилам помощи государствам-членам с низким доходом на душу населения, а также значительно укрепил свою кредитоспособность. Фонд начал трансформироваться в организацию, которая не только дает в распоряжение финансовые ресурсы и предоставляет техническую помощь членам у которых проблемы с платежным балансом, но и тем, кто борется с социальными проблемами и проблемами развития - в основном с бедностью.

Новые инициативы МВФ способствуют повышению эффективности проводимых в государствах-членах экономических реформ, а также реализованных программ перестройки и развития, что является важным вкладом организации в стратегию устойчивого развития. 